Swarthmore College

Works

$4-1-2001$

\title{
Bird Migration Through A Mountain Pass Studied With High Resolution Radar, Ceilometers, And Census
}

Timothy C. Williams , '64

Swarthmore College, twillia1@swarthmore.edu

J. M. Williams

P. G. Williams

P. Stokstad

Follow this and additional works at: https://works.swarthmore.edu/fac-biology

Part of the Biology Commons

Let us know how access to these works benefits you

\section{Recommended Citation}

Timothy C. Williams , '64; J. M. Williams; P. G. Williams; and P. Stokstad. (2001). "Bird Migration Through A Mountain Pass Studied With High Resolution Radar, Ceilometers, And Census". Auk. Volume 118, Issue 2. 389-403. DOI: 10.1642/0004-8038(2001)118[0389:BMTAMP]2.0.C0;2

https://works.swarthmore.edu/fac-biology/255

This work is brought to you for free by Swarthmore College Libraries' Works. It has been accepted for inclusion in Biology Faculty Works by an authorized administrator of Works. For more information, please contact myworks@swarthmore.edu. 
Bird Migration through a Mountain Pass Studied with High Resolution Radar, Ceilometers, and Census

Author(s): Timothy C. Williams, Janet M. Williams, Peter G. Williams and Paul Stokstad

Source: The Auk, Vol. 118, No. 2 (Apr., 2001), pp. 389-403

Published by: American Ornithologists' Union

Stable URL: http://www.jstor.org/stable/4089800

Accessed: 27-04-2015 14:35 UTC

\section{REFERENCES}

Linked references are available on JSTOR for this article:

http://www.jstor.org/stable/4089800?seq=1\&cid=pdf-reference\#references_tab_contents

You may need to log in to JSTOR to access the linked references.

Your use of the JSTOR archive indicates your acceptance of the Terms \& Conditions of Use, available at http://www.jstor.org/page/info/about/policies/terms.jsp

JSTOR is a not-for-profit service that helps scholars, researchers, and students discover, use, and build upon a wide range of content in a trusted digital archive. We use information technology and tools to increase productivity and facilitate new forms of scholarship. For more information about JSTOR, please contact support@jstor.org. 


\title{
BIRD MIGRATION THROUGH A MOUNTAIN PASS STUDIED WITH HIGH RESOLUTION RADAR, CEILOMETERS, AND CENSUS
}

\author{
Timothy C. Williams, ${ }^{1,5}$ Janet M. Williams, ${ }^{1}$ Peter G. Williams, ${ }^{2,3,6}$ AND \\ PAUL STOKSTAD ${ }^{4}$ \\ ${ }^{1}$ Department of Biology, Swarthmore College, Swarthmore, Pennsylvania 19081, USA; \\ ${ }^{2}$ P.O. Box 58, Franconia, New Hampshire 03580, USA; \\ ${ }^{3}$ College of the Atlantic, Bar Harbor, Maine 04609, USA; and \\ ${ }^{4} 150$ Hill Road, Berkeley, California 94708, USA
}

\begin{abstract}
Autumnal migration was studied with high-resolution radar, ceilometer, and daily census in the area of Franconia Notch, a major pass in the northern Appalachian Mountains. Under synoptic conditions favorable for migration, broadfront movements of migrants toward the south passed over the mountains, often above a temperature inversion. Birds at lower elevations appeared to be influenced by local topography. Birds moving southwest were concentrated along the face of the mountain range. Birds appeared to deviate their flights to follow local topography through the pass. Specific migratory behavior was not associated with species or species groups. Under synoptic conditions unfavorable for southward migration, multimodal movements probably associated with local flights were as dense as the southward migrations described above. Avian migrants reacting to local terrain may result in concentrations of migrants over ridge summits or other topographic features. $R e$ ceived 29 November 1999, accepted 2 November 2000.
\end{abstract}

NORTH AMERICAN nocturnal migrants as observed with radar, a light beam (ceilometer), or by moon-watching appear to use broadfront migration, moving in waves hundreds of kilometers wide and rarely responding to features of the terrain until they descend for landing (Lowery and Newman 1966, Able 1972, Richardson 1972, Williams et al. 1977). Evidence for deviation of nocturnal flights along features of the terrain such as rivers, coastlines, or hills is rare in North America (Richardson 1978a, Bingman et al. 1982, McCrary et al. 1983). In contrast to North America, moon-watching, infrared, and radar observations in Europe have revealed birds deviating to follow coastlines, river systems, and most obviously the Alps (Eastwood 1967, Bruderer 1978, 1999; Bruderer and Jenni 1988, 1990; Jellmann 1988, Liechte et al. 1996, Bruderer and Liechte 1999). It is not clear whether those differences are due to North American birds relying more heavily on fixed-heading orientation (Wiltschko and Wiltschko 1978, Berthold 1990, Williams 1991, Williams and Webb 1996) or to other factors. Mountains, especially those presenting a bar-

\footnotetext{
${ }^{5}$ E-mail: twillia1@swarthmore.edu

6 Present address: SE Group, Mountain View Center II, 610 Main St., P.O. Box 2729, Frisco, Colorado 80443, USA.
}

rier transverse to the direction of migration, would present the most critical test of theories that posit fixed-heading migrations for North American migrants. The behavior of nocturnal migrants in mountainous areas is also important for conservation issues because alpine areas are increasingly developed in North America for projects such as communication towers and wind-powered generators.

Bruderer and his coworkers have observed bird migration in the Swiss Alps (Bruderer 1978, 1996; Bruderer and Jenni 1988, 1990), but the orientation and flight behavior of nocturnal avian migrants in mountainous terrain has been rarely studied in North America (Seilman et al. 1981, McCrary et al. 1983). Radar is poorly suited for use in mountainous areas due to echoes from surfaces rising above the horizontal. To study nocturnal migration in mountains, it is necessary to use high-resolution short-range radars and move the instruments either between nights, as was done by Bruderer and Jenni (1990), or use a mobile radar and move it rapidly between sites within a single night as did Seilman et al. (1981). Alternatively, one can use ceilometers or a number of moon-watching stations as did Liechti et al. (1996). In side-byside tests, ceilometers and short range, highresolution radars produce highly correlated 
measures of direction and density of bird migration and survey a similar range of altitudes above ground level (Williams et al. 1981, Bruderer 1999).

If birds use a variety of orientation systems in North America, it would be important to identify which species of birds use which system. Birds observed with radar or ceilometers, however, can rarely be identified to species (Williams and Williams 1980). Changes in the numbers of birds on the ground (diurnal census) have been only weakly associated with nocturnal radar or ceilometer observations (Drury and Keith 1962, Nisbet and Drury 1967, Williams et al. 1977, Bruderer and Jenni 1990). Williams et al. (1981) paired radar, ceilometer, and intensive mist-netting in southeastern Massachusetts. Numbers of birds detected with radar and ceilometers were highly correlated with each other, but were not significantly correlated with numbers of birds netted the next morning.

The present study reports radar and ceilometer observations of nocturnal migration in the Franconia Range of the White Mountains of New Hampshire and simultaneous daily censuses of birds at several sites in a variety of habitats. Those mountains are part of the Appalachian Mountain chain, which stretches from the breeding grounds of numerous migrant species in New England and Canada to wintering grounds of many North American migrants in the southeastern United States (see Fig. 1, inset). The Franconia Range runs northeast to southwest and rises about $1,000 \mathrm{~m}$ from the lowlands that stretch northwest to the Connecticut River. Franconia Notch is a pass that runs roughly north to south through this barrier (Fig. 1). The mountain range is large enough to interrupt flight of birds, but low enough that they can easily fly over it (Eastwood 1967, Williams et al. 1977).

Previous radar studies have shown two principal directions of autumnal migration in New England. Neotropical migrants move through that area toward the south and southeast on a route to Central and South America whereas North American migrants move southwest parallel to the coastline (Drury and Keith 1962, Williams et al. 1977). For the Neotropical migrants, those mountains constitute the largest mountain barrier on the route from Canada to the North American coast and the Neotropics.

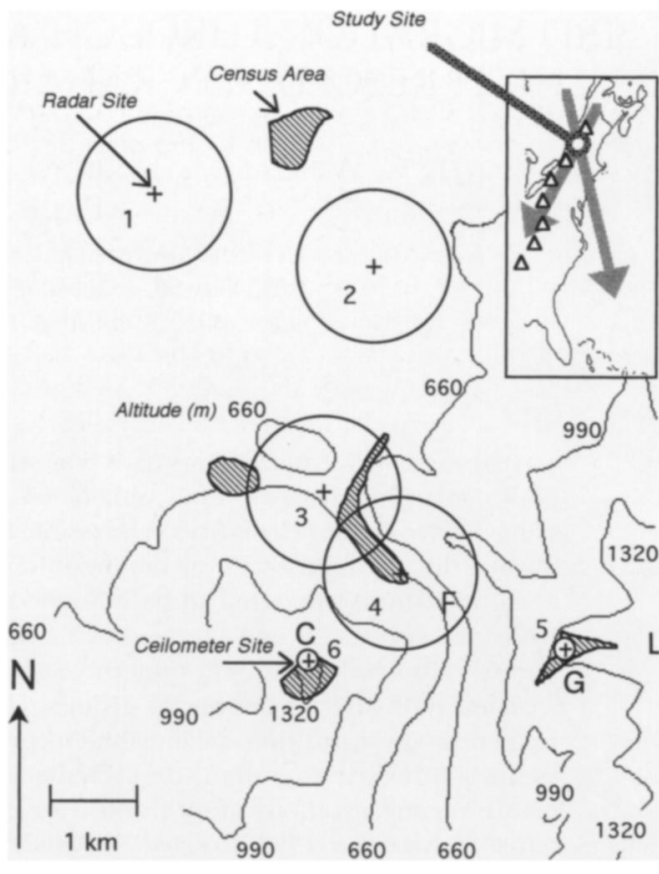

FIG. 1. Franconia Notch in the White Mountains of New Hampshire, $44^{\circ} 10^{\prime} \mathrm{N}, 71^{\circ} 41^{\prime} \mathrm{W}$. The Franconia Range of mountains stretches northeast to southwest across the figure. Contour intervals are $330 \mathrm{~m}$. The floor of the notch (F) is flanked by Cannon Mountain (C) and Mt. Lafayette (L). Greenleaf Hut (G) is located on a shoulder of Mt. Lafayette. Nocturnal observation sites identified by number. Large circles show maximum range for detection of birds by radar at observation sites 1-4. At sites 3 and 4, significant areas within this maximum were obscured by local topography. Small circles indicate ceilometer observation at sites 5 and 6 . Hatched areas indicate census areas. Inset indicates location of Franconia Notch in the Appalachian Mountain chain and movements of Neotropical (southsoutheast) and North American (southwest) migrants.

For the North American migrants, the mountains form a major topographical feature parallel to their migration. If migrants were guided by fixed-heading orientation, we would expect broadfront migration to move as a wave up and over the mountains. If we found significant differences in the orientation of birds in the lowlands and over the mountains, that might indicate the existence of a second orientation system based on topography.

\section{METHODS}

We performed daily point-count and area-count censuses from near local sunrise to noon EST in the 
3 to 10 ha areas shown in Figure 1. We made observations in all but the most northern area daily from 26 August to 11 October 1992. From 22 August to 17 October 1993, we observed daily at the most northern site. That was a mixed forest site in the lowlands $(400 \mathrm{~m})$, which included coniferous and hardwood forest, fields, and wetlands, $3 \mathrm{~km}$ northwest of the Franconia Range. The ecology of the multiple sites used in 1992 were as follows: the alpine sites around Greenleaf Hut on the shoulder of Mount (Mt.) Lafayette $(1,300$ to $1,400 \mathrm{~m}$, see Fig. 1$)$ and on the summit of Cannon Mountain (1,300 m) included areas of alpine meadow, krumholtz, and alpine coniferous forest. All vegetation at those sites was $<4 \mathrm{~m}$ high and in most areas $<2 \mathrm{~m}$. Two lower elevation areas on the floor of the northern end of Franconia Notch $(650 \mathrm{~m}$, Fig. 1) included open fields, lake shore, and mixed forest.

We restricted our analysis to species for which we observed at least five individuals in one day. The 42 species of passerines and 2 species of woodpeckers that met that criterion are listed in Appendix. A group of Neotropical warbler species, which often moved in mixed flocks in association with each other, were treated as a single species for analysis. All the species in Appendix, both migrants and nonmigrants, except for the Bay-breasted Warbler, the Wilson's Warbler, and the White-crowned Sparrow, breed within the study area and were observed at lower densities during the breeding season.

The raw numbers of birds seen per day could not be used as a measure of migratory activity, especially in alpine areas. Local weather conditions ranged from clear, windless days at $25^{\circ} \mathrm{C}$ to $15 \mathrm{~m} \mathrm{~s}^{-1}$ winds, snow and $-10^{\circ} \mathrm{C}$. To correct for fluctuations in number of birds counted due to changes in local weather, we created an index of migratory activity. Each day's count of migrant species was expressed relative to the abundance of nonmigrant species and then compared with the previous day to produce a three-point index of major change in numbers of migrants ( $>50 \%$ change), minor change (50 to $21 \%$ change), and stable numbers ( $<20 \%$ change).

Wind direction and speed, temperature, cloud cover, and visibility conditions were recorded at ground level for each site during both morning and nocturnal observations. We also obtained hourly surface weather observations from the Fairbanks Museum in St. Johnsbury, Vermont (37 km northwest of the study site, elevation $175 \mathrm{~m}$ ) and from the Mt. Washington Observatory ( $32 \mathrm{~km}$ northeast, elevation 2,068 $\mathrm{m})$. We used surface and $850 \mathrm{mb}$ weather charts and our local weather measurements to code synoptic weather on a five-point scale. The synoptic weather code, based on Gauthreaux (1980), reflects the synoptic weather system that most strongly affects local weather and does not always correspond to the synoptic feature geographically closest to the study area on a given night. Wind velocity was too variable within the mountainous areas to permit reliable calculation of headings from track and wind velocities; we frequently recorded differences of $120^{\circ}$ and $5 \mathrm{~m}$ $\mathrm{s}^{-1}$ within distances of $100 \mathrm{~m}$. Measurements by local meteorologists (Pat Gannon pers. comm.) indicate that such large deviations are common up to $100 \mathrm{~m}$ above ground level (AGL) in the study area. Thermal inversions were identified directly by comparison of temperature readings at different altitudes.

We observed nocturnal migration at two alpine sites (site 5 at $1,396 \mathrm{~m}$ and site 6 at 1,315 m; see Fig. 1) by watching birds pass through a vertically directed conical light beam, or ceilometer, as described by Gauthreaux (1969) and Able and Gauthreaux (1975). We observed with either $10 \times 50$ or $8.5 \times 44$ binoculars. On Cannon Mountain, we used a GE Ceilometer bulb 100PAR64. At Greenleaf Hut, where battery power was at a premium, we used a Custom Accessories model 58886, 300,000 candle power spotlight. Although beam width was not specified, tests showed that the beam on this unit was narrower and the range of detection similar to that of the ceilometer bulb.

We made simultaneous observations with ceilometer and radar for one hour on all 30 nights with suitable weather from 28 August to 10 October 1992, starting one hour after civil sunset. Observations were not made in rain, snow, or fog, or when the cloud ceiling was less than $100 \mathrm{~m}$ AGL. On eight additional nights without heavy rain in the same period, we were able to observe with radar alone. Gauthreaux (1969) and Able and Gauthreaux (1975) report that the maximum altitude of detection of the ceilometer we used is $500 \mathrm{~m}$ AGL for thrush-sized passerines. We estimated that most birds we detected were between 10 and $300 \mathrm{~m}$ AGL based on image size and rate of passage through the light beam.

We used a mobile, high resolution, modified marine radar to record nocturnal migration at sites 1, 2, 3 , and 4 shown in Figure 1. The Furuno FR-8100 Xband marine radar (peak power $10 \mathrm{~kW}$, beam width $1.8 \times 25^{\circ}$, antenna rotation $24 \mathrm{RPM}$ ) was operated at $0.91 \mathrm{~km}$ range and $0.08 \mu \mathrm{s}$ pulse length. The radar was modified by tilting the antenna upwards $12.5^{\circ}$ above horizontal and was mounted on a van. Data from the display of the radar were recorded on video tape. We used a $30 \mathrm{~s}$ echo trail function allowing immediate recognition of bird echoes on the radar screen. Direction of movement was read with the electronic bearing line to $\pm 2^{\circ}$. To ensure that all azimuths of the radar display had an equal probability of being detected, we began observations at $0^{\circ}$ azimuth of the radar and moved constantly clockwise to select the next track, always completing the full $360^{\circ}$ before repeating an azimuth. The great majority of tracks were separated by $100 \mathrm{~m}$ to $1 \mathrm{~km}$. Those tracks were not used to determine the density of migration (see below). 
Radar observations started about one hour after civil sunset and continued for 1-2 $h$ to overlap the ceilometer observations. At all radar sites, low trees or hills near the radar were used as a radar fence to reduce ground clutter and facilitate detection of birds at short range (see Seilman et al. 1981). Site 1 $(367 \mathrm{~m})$ and site $2(481 \mathrm{~m})$ were free of major obscuration. Site $3(569 \mathrm{~m})$ and site $4(601 \mathrm{~m})$ had strong echoes from the east and west walls of the pass (see Fig. 1), which restricted detection of birds to about $50 \%$ of the radar screen in those areas. Observations were made for $5 \mathrm{~min}$ at sites 1,2 , and 4 and for 10 min at site 3 , which was subdivided into four areas. (The northwest and northeast quadrants of site 3 were north of the entrance to the pass and the southwest and southeast quadrants were within the pass.) The radar was moved between sites in less than 10 min and aligned to within $3^{\circ}$ using reflective markers at each site. Observations at each site were made at least twice each night at intervals of $\sim 45 \mathrm{~min}$. That technique provided samples ranging from 0 to 146 tracks (average $=29$ ) at each site for each night. The altitude of birds detected was estimated by the technique of Cohen and Williams (1980) using track curvature as recorded on video tapes. That analysis indicated that $90 \%$ of all birds were detected at an elevation angle of $<30^{\circ}$. Because the great majority of birds were detected at $<600 \mathrm{~m}$ range, we conclude that $90 \%$ of all tracks were at $<300 \mathrm{~m}$ AGL.

To determine relative migration density for the radar observations, we used an arbitrary index, "the track density index." Video-tape records were reviewed and the number of tracks detected in a standard area of the radar screen was determined for four, $30 \mathrm{~s}$ periods at each site. (The location of those standard areas differed at each radar site.) In analyses, we summed the total of those counts for all sites for a night and termed that the "track density index."

It is unlikely that the ceilometer or radar data used for analysis were contaminated by significant numbers of insect tracks. Gauthreaux's (1969) ceilometer technique minimizes insect observations. Insects were detected by the radar, but they differed from bird tracks in echo intensity, range of detection, and straightness of track. All suspected insect tracks identified by those criteria were excluded from our analysis. Very few tracks reported in this study were detected at $<180 \mathrm{~m}$ range, thus further reducing the risk of contamination by insects. We measured flight speeds for tracks detected by our radar on seven nights when wind velocity at all radar sites was $<3$ $\mathrm{m} \mathrm{s}^{-1}$. The average flight speed was $10.0 \mathrm{~m} \mathrm{~s}^{-1}$ and the range was from 4 to $22 \mathrm{~m} \mathrm{~s}^{-1}$. Larkin (1991) reports that insect-like echoes detected with a tracking radar had a mean flight speed of $\sim 4 \mathrm{~m} \mathrm{~s}^{-1}$ with a range of 1 to $10 \mathrm{~m} \mathrm{~s}^{-1}$, whereas bird-like echoes had a mean flight speed of $\sim 11 \mathrm{~m} \mathrm{~s}^{-1}$ with a range of 2 to $22 \mathrm{~m} \mathrm{~s}^{-1}$. Comparison of our flight-speed data with those of Larkin (1991) and with the flight speeds of birds reported by Bloch and Bruderer (1982) and by Raynor (1985) indicate that the great majority of radar tracks reported in this study were of passerine birds. Larkin (1991), however, found that insects dominated the radar echoes on nights with winds unfavorable for bird migration; thus, it is possible that we detected insects when winds were from the south and we were not able to compute airspeeds due to turbulent wind conditions.

Parametric statistics were not used in the analysis of directions because of marked deviations from circular normal distributions. Analysis of directional data followed Batschelet's (1981) nonparametric $\chi^{2}$ test, which is a contingency table with rows consisting of the bins of track directions shown in our circular histograms and columns for the criteria to be tested. In all $\chi^{2}$ tests, rows or columns were summed if expected values were $<5$. Wide separation of tracks used for directional data satisfies the requirement for independence of data points. No one observation dominated the analyses as the maximum number of tracks at any site for any night was 146 $(1.7 \%)$ of the total of 8,668 tracks. The $\chi^{2}$ test will detect significant differences due to any association between directional distribution and criteria. Especially in tests with large $n$, significant differences may not be due to a shift in the modal direction(s) of tracks but to differences in dispersion around the modes or to numbers of tracks in nonmodal directions. To control for that effect we used a second method. Before any other analyses were performed, we scored each night of migratory behavior as one of four patterns of track directions. Southward (S) movements often had a second modal direction to the southeast. Southwestward (SW) movements often had a second mode to the south. Eastward and westward (E-W) patterns were usually scattered but with modes to the east or west, or frequently to both directions. Northward (N) patterns had modal directions ranging from northwest to northeast. We then used $\chi^{2}$ tests to compare the distribution of nightly patterns with criteria to be tested. That method suffered from the necessity of qualitatively scoring each night as one of four types of migratory behavior.

\section{RESULTS}

Direction and density of nocturnal migrants detected with radar and ceilometers were compared with changes in species counts from daily censuses. We first describe diurnal census data and then nocturnal observations before proceeding with comparisons.

Daily census.-Daily censuses of birds were made at locations shown in Figure 1. We distin- 

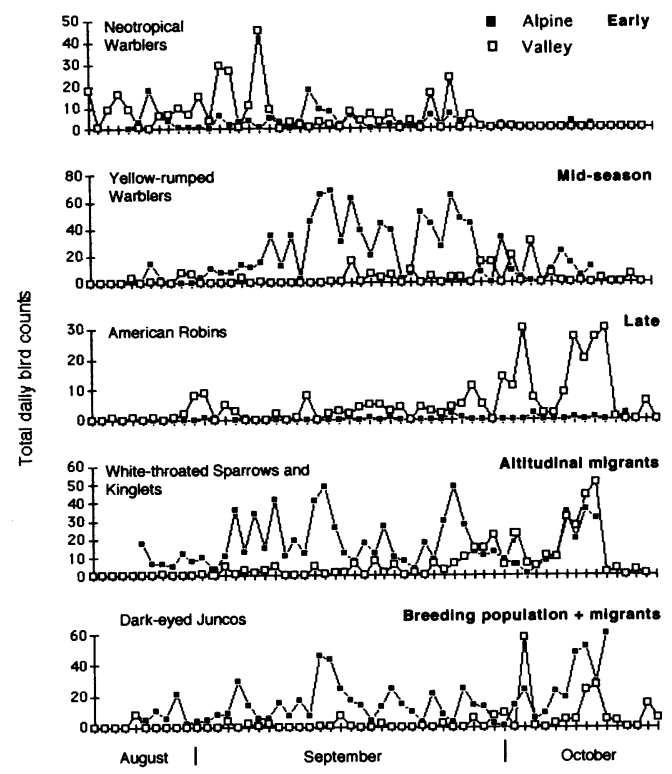

FIG. 2. Daily census of most numerous species for all major migrant status groups we observed in the area of Franconia Notch, New Hampshire in 1992 and 1993 (see Appendix A for other species). Solid squares (alpine) are data from observations at 1,300$1,400 \mathrm{~m}$ elevation (see text for habitat descriptions). Open squares (valley) are data from observations at 500-600 m elevation. Neotropical Warblers do not include Yellow-rumped Warblers. High counts in late September included in early migrants are Blackpoll Warblers which are mid-season migrants but are included in Neotropical warbler group.

guished five status groups of birds (described below) based on these. Appendix gives the status of each of the 42 species used in analysis and daily average and maximum counts of birds for each species at alpine and low-elevation areas. Daily counts for the most numerous species in each status group are given in Figure 2. Early migrants consisted of warblers and small numbers of other passerines that showed peak numbers at valley locations in August and early September and then decreased in mid September (Fig. 2, Early). Yellow-rumped Warblers at alpine locations were the most numerous midseason migrants. They increased in numbers in early to mid September and decreased in mid to late September (Fig. 2, Midseason). Blackpoll Warblers, mid-season migrants, were included with other Neotropical warblers in Figure 2 (Early) and show up as peaks in mid and late September. Late-season migrants, primarily American Robins and
Dark-eyed Juncos at valley locations, increased in September and early October and did not decrease during the period of our observations (Fig. 2, Late). Altitudinal migrants, mainly White-throated Sparrows and Goldencrowned Kinglets (Regulus satrapa), shifted from alpine to low-elevation areas (Fig. 2, Altitudinal). Dark-eyed Juncos (Fig. 2, Breeding + migration) illustrate the interaction of several factors: an alpine breeding population in August was joined at alpine sites by migrants, formed large flocks and moved between alpine and valley sites depending on weather conditions. At each site, we also defined a group of "nonmigrant" species that did not show any significant change in numbers during the period of our observations, although those species may migrate in other areas or later in the season. Blue Jays, Black-capped Chickadees, nuthatches, Song Sparrows, and Evening Grosbeaks constituted the majority of the nonmigrant birds.

Simultaneous censuses in alpine and low-elevation communities revealed major differences in the numbers of migrants. Most migrant species arrived and departed at different times in those areas (Fig. 2). Alpine migrants consisted primarily of Yellow-rumped Warblers with smaller numbers of Bicknell's Thrushes and Blackpoll Warblers. Most other early and midseason migrants, including warbler species migrating to the Neotropics, were seen in greater numbers at lower elevations although small numbers were often seen at alpine sites the morning after a migration. Late-season migrants such as American Robins appeared primarily at lower elevations during October (Fig. 2, Late).

Migratory activity, scored on a three-point migration index (see above), was associated with changes in synoptic weather conditions over the study area. Synoptic weather was coded on a five-point scale illustrated in Figure 3B and described in Table 1. Heavy migration as indicated by large changes in numbers of $\mathrm{mi}-$ grants was associated with weather code 1 . Minor changes in numbers of migrants were associated both with synoptic weather code 2 and with codes 4 and 5 . Stable numbers of migrants were associated with weather code $3\left(\chi^{2}=\right.$ 12.70, df $=4, P=0.0129$ ).

Site-to-site fluctuations during periods of overall stable populations and shifts from al- 
A
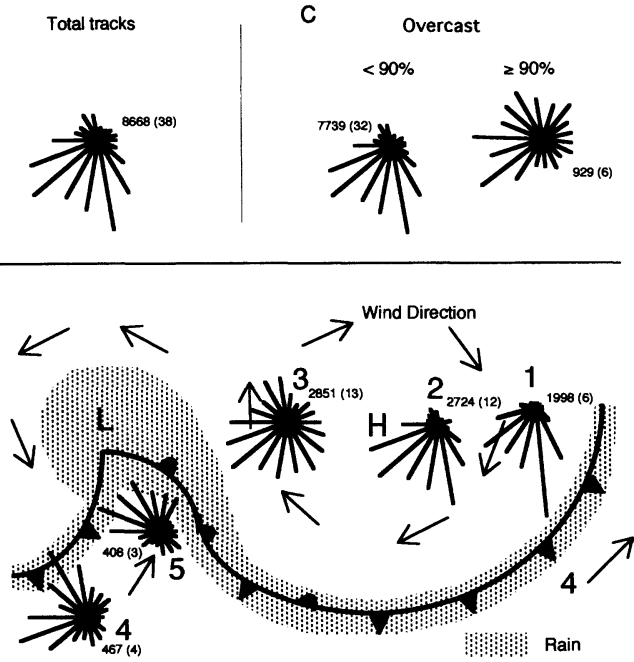

FIG. 3. A. Distribution of all tracks scored for directional data in 1992. B. Synoptic weather codes, geostrophic wind direction, areas likely to have rain, and distribution of track directions presented on a schematic synoptic weather map. See Table 1 for weather conditions associated with synoptic codes. C. Distribution of tracks under two conditions of overcast. Circular histograms give frequency of track directions in $20^{\circ}$ bins. $N$ of tracks followed by ( $n$ of nights) are given near histograms. Note $n$ of tracks does not accurately represent density of migration, see text for independent density measurement.

pine to low-elevation areas (Fig. 2) indicate local movements within the study area. On several occasions, we could watch large flocks of Dark-eyed Juncos arrive at a census area, move through it, and then fly to another area at least $0.5 \mathrm{~km}$ away. We also observed that a sudden local abundance of food, such as outbreaks of lepidopteran larvae in birch stands (Betula spp.), attracted warblers in sufficient numbers to suggest movements over several kilometers to the feeding area.

Radar and Ceilometer observations.--Radar and ceilometers revealed large numbers of $\mathrm{mi}$ grants passing through our study area. A total of 8,668 tracks of birds were scored for analysis of flight direction and 4,471 tracks were scored to determine density of migration (see above). There were no significant differences in the average density of migration at the four radar sites when numbers were adjusted for site specific obscuration of the radar (see above). The maximum density of birds detected with the ceilometers was 215 birds per hour at site 5 . The maximum density detected with the radar was 151 tracks in four, 30 s periods at site 2 or 4,530 tracks per hour detected in an area of $\sim 160,000$ $\mathrm{m}^{2}$. The same radar and ceilometer equipment operated in September and October for four years (1994, 1995, 1997, and 1999) in relatively flat terrain in Swarthmore, Pennsylvania, did not record migrations as dense as those.

Although we lacked the ability to determine altitude accurately, it was our impression that on nights of heavy southward migration over the two ridge sites ( 5 and 6 ) there were exceptional numbers of migrants at 2 to $30 \mathrm{~m}$ AGL. The density was such that observers without binoculars could often see birds at close range in the relatively dim light scattered from the ceilometer. We have not seen as many low-flying birds in other observations with ceilometers over level terrain.

The distribution of all track directions observed with radar and ceilometers for all sites was bimodal with similar numbers of birds moving southsoutheast $\left(n=1,078\right.$ at $\left.170^{\circ}\right)$ and southwest ( $n=1,023$ at $230^{\circ}$; Fig. 3 ). Those two modal directions correspond to southwest movement parallel to the face of the Franconia Range and by extension along the Appalachian Mountains in general, and a southsoutheast movement across the mountains toward the Atlantic Ocean (see Fig. 1). Multimodal distributions of direction were common at all levels of analysis from single 5 min observation periods to summed data for all nights. Tracks were not usually distributed around a preferred direction but instead suggested two or more preferences as above.

Synoptic weather pattern was a major factor in orientation and density of nocturnal migration. Synoptic weather codes 1 and 2 (Fig. 3B, Table 1) are favorable for southward migrations. We found migration generally heavy and toward the south or southwest on these nights (Fig. 3B, Table 1). Density measurements in Table 1 are based on a 2 min density sample, not the number of tracks scored for direction. The greatest number of birds detected by radar and ceilometers was moving south with smaller numbers moving southwest (Fig. 3B). On nights with synoptic code 2 , the radar recorded somewhat lower densities of tracks and the directions of bird movements were about evenly distributed between south and southwest (Fig. 3B, Table 1). Synoptic codes 3, 4, and 5 repre- 
TABLE 1. Change in the numbers of migrants detected overnight and nocturnal migratory behavior associated with five synoptic weather codes.

\begin{tabular}{|c|c|c|c|c|c|}
\hline Weather Code & 1 & 2 & 3 & 4 & 5 \\
\hline $\begin{array}{l}\text { Synoptic feature that most af- } \\
\text { fected local weather }\end{array}$ & $\begin{array}{l}\text { North or west } \\
\text { of a cold } \\
\text { front }\end{array}$ & $\begin{array}{l}\text { Near center } \\
\text { of a high }\end{array}$ & $\begin{array}{l}\text { West of a } \\
\text { high }^{\mathrm{a}}\end{array}$ & $\begin{array}{l}\text { South or } \\
\text { east of a } \\
\text { cold front }\end{array}$ & $\begin{array}{c}\text { South of a } \\
\text { warm } \\
\text { front }\end{array}$ \\
\hline $\begin{array}{l}\text { Typical wind (large local var- } \\
\text { iation) }\end{array}$ & $\begin{array}{l}\text { North moderate } \\
\text { to strong }\end{array}$ & $\begin{array}{l}\text { Calm or light } \\
\text { north to } \\
\text { west }\end{array}$ & $\begin{array}{l}\text { South light to } \\
\text { moderate }\end{array}$ & $\begin{array}{l}\text { South light to } \\
\text { moderate }\end{array}$ & $\begin{array}{l}\text { South light to } \\
\text { moderate }\end{array}$ \\
\hline \multicolumn{6}{|l|}{$\begin{array}{l}\text { Census }(1992+1993) n \text { of } \\
\text { nights with: }\end{array}$} \\
\hline $\begin{array}{l}\text { Large changes in } n \text { of mi- } \\
\text { grants }\end{array}$ & 9 & 8 & 2 & 2 & 1 \\
\hline $\begin{array}{l}\text { Minor changes in } n \text { of } \mathrm{mi}- \\
\text { grants }\end{array}$ & 7 & 8 & 8 & 2 & 2 \\
\hline Stable $n$ of migrants & 0 & 4 & 8 & 2 & 0 \\
\hline \multicolumn{6}{|l|}{ Radar and ceilometer (1992) } \\
\hline $\begin{array}{l}n \text { of nights } \\
\text { Density (track density index) }\end{array}$ & 6 & 12 & 13 & 4 & 3 \\
\hline Maximum & 199 & 259 & 185 & \multicolumn{2}{|c|}{$148^{c}$} \\
\hline Minimum & 127 & 24 & 31 & \multicolumn{2}{|c|}{$24^{c}$} \\
\hline Average & 169.7 & 114.5 & 124.0 & \multicolumn{2}{|c|}{$66.7^{c}$} \\
\hline Standard deviation & 26.6 & 76.9 & 48.4 & \multicolumn{2}{|c|}{$46.3^{c}$} \\
\hline \multicolumn{6}{|l|}{$\begin{array}{l}n \text { of nights with track } \\
\text { pattern }^{\mathrm{b}}\end{array}$} \\
\hline South & 2 & 2 & 0 & 0 & 0 \\
\hline Southwest & 4 & 9 & 1 & 0 & 0 \\
\hline East-west & 0 & 1 & 11 & 2 & 2 \\
\hline North & 0 & 0 & 1 & 2 & 1 \\
\hline
\end{tabular}

a Center of high pressure.

${ }^{b}$ Most nights had multimodal track distributions. See methods for definitions of track patterns.

'Summed data for weather codes 4 and 5.

sent conditions unfavorable for southerly migrations. Under those weather conditions, tracks were widely scattered or moving generally north, but the density of birds aloft was often as high as for southward migration, especially for weather code 3 . On nights with weather code 3 , radar and ceilometers showed a broad spread of track directions with the greatest numbers moving southwest (Fig. 3B). Synoptic code 4 was accompanied by bird movements to both the southwest and the northwest (Fig. 3B). In synoptic code 5 (Fig. 3B), tracks were directed primarily northwest. Analysis of variance showed a significant difference in track-density index for the weather codes $(F=3.62, P=0.023)$. Pairwise comparisons of density indicated significant differences at $P<0.05$ only for weather codes 1 versus combined 4 and 5 , and 3 versus combined 4 and 5 . There were no significant differences in density between codes 1,2 , and 3 . The distribution of track direction (Fig. 3) was significantly dif- ferent for the five synoptic weather codes $\left(\chi^{2}=\right.$ $1,790, \mathrm{df}=68, P<0.0001$ ).

In addition to analyzing summed tracks for all nights, we also investigated whether the nightly pattern of movement was associated with synoptic weather by scoring each night in one of four patterns (Table 1). Synoptic codes 1 and 2 were associated with nightly modal directions to the south or the southwest whereas synoptic codes 3,4 , and 5 were associated with nights having modal track directions toward the north, east, or west $\left(\chi^{2}=30.4, \mathrm{df}=1, P=\right.$ 0.0001 ).

On the six nights with more than $90 \%$ overcast, we recorded more scattered tracks than on clear or partially overcast nights $\left(\chi^{2}=440, \mathrm{df}\right.$ $=17, P<0.0001$; Fig. $3 C$ ). There was no significant difference in track density index: the average for overcast nights was $92.8 \pm 67.7$, and for partial or clear nights $122.3 \pm 61.5(F=$ $1.127, P=0.295)$. View of the stars or sky was not necessary for orientation. On both overcast 
nights with synoptic code 1 or 2 , tracks were directed southwest. On the two nights with synoptic codes 4 or 5 , tracks were directed northwest to northeast. On two nights with code 3 , tracks were generally southwest. The multimodal nature of the distributions and the small number of overcast nights prevented our testing whether downwind flight was more common under overcast.

The effect of topography on direction of bird movements was investigated by comparing simultaneous observations made in lowlands north of the mountains, within the mountain pass, and on ridges above the pass. Patterns of tracks recorded at six nocturnal observation sites shown in Figure 1 were significantly different $\left(\chi^{2}=1,686, \mathrm{df}=85, P<0.0001\right)$. At sites 1 and 2 in the lowlands, modal direction of movement was southwest, whereas within the mountains (sites $3,4,5$, and 6) the most common direction was southsoutheast. The differences in orientation within our study area were most clearly shown when we considered the behavior of birds under each type of synoptic weather. In the following discussion, we will refer to birds detected at sites 1 and 2 (Fig. 1) as above lowlands northwest of the Franconia Range, or "above the lowlands." Birds detected at sites 3 and 4 are within the pass (Franconia Notch) and its northern approaches and will be termed "in the pass," and birds seen at sites 5 and 6 , on ridge tops about $660 \mathrm{~m}$ above the pass, will be referred to as "above the ridges." Sites 3, 4, 5, and 6 together will be called "in the mountains."

Under synoptic code 1, birds above ridges and in the pass were moving primarily southsoutheast, whereas birds above the lowlands to the northwest of the mountains were moving primarily southwest with smaller numbers of birds moving south (Fig. 4). These differences are unlikely to be due to altitude alone because sites 2 (in the lowlands) and 3 (in the pass) differed by only $88 \mathrm{~m}$, considerably less than the $300 \mathrm{~m}$ altitude range of the radar.

For synoptic code 2, we also observed predominantly southsoutheast movements above ridges and in the pass and southwest movements above lowlands (Fig. 4). Unlike code 1 weather conditions, we also found large numbers of birds moving southwest within the pass and over the western ridge area. Winds were near calm at almost all sites; on only two nights

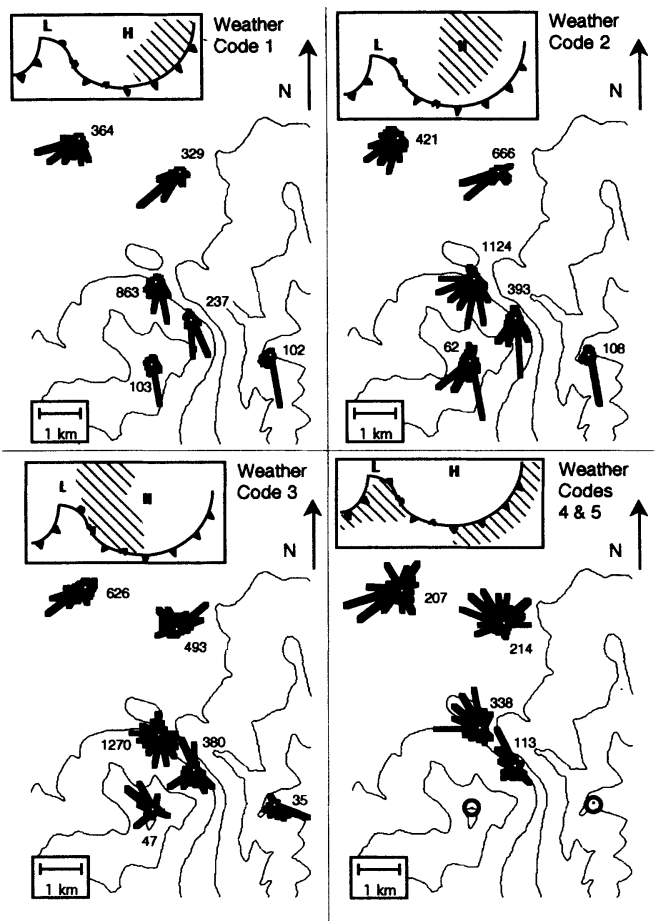

FIG. 4. Distribution of tracks of nocturnal migrants at six observation sites in Franconia Notch, New Hampshire, on nights scored for synoptic weather codes as indicated (see text). Inset shows area of general synoptic pattern. Circular histograms give frequency of directions in $20^{\circ}$ bins of all scored tracks on these nights. The two most southerly histograms show ceilometer data taken at 1,300 and $1,400 \mathrm{~m}$; all others are from radar at $500-600 \mathrm{~m}$. $N$ of tracks given for all histograms; circle indicates insufficient data for analysis, $n$ of nights given in Table 1 and Figure 3 . Note $n$ of tracks does not accurately represent density of migration, see text for independent density measurement.

did we record winds $>4 \mathrm{~m} \mathrm{~s}^{-1}$ and then only on ridges. On four of the 12 nights scored synoptic code 2 , winds were calm at all our observation sites and at all other meteorological stations in the area and, thus, orientation was not due to downwind orientation. All of those nights showed patterns of track directions similar to those shown in Figure 4 for weather code 2.

The difference between birds moving within the mountains and those moving along the north slope of the range was most pronounced in the subareas of site 3 (see above) at the entrance to the pass (Fig. 1). For summed data from weather codes 1 and 2, tracks north of the entrance to the pass showed a bimodal distri- 
bution with about half the birds moving into the pass (mode $\left.=170^{\circ}\right)$ and half moving across the entrance $\left(\right.$ mode $\left.=230^{\circ}\right)$. Within the pass, tracks showed a unimodal distribution centered around $180^{\circ}$.

Differences in modal track directions between the lowlands and the mountain sites were associated with presence of thermal inversions. We recorded thermal inversions on 11 nights with synoptic weather codes 1 or 2 . Winds on those nights were calm to light over the lowlands and on the floor of the pass, and typically 5 to $12 \mathrm{~m} \mathrm{~s}^{-1}$ from the north at ridge summits. On 9 of these 11 nights, the pattern of migration at lowland and mountain sites had different modal directions; on 2 nights they had the same pattern. Of the seven nights without inversions, five showed the same modal patterns for lowland and mountain sites and only two showed differences $\left(\chi^{2}=5.1, \mathrm{df}=1, P=\right.$ $0.02)$. The differences in track direction above and below the inversion in most cases could be ascribed to differences in wind velocity, but on three nights with inversions winds were recorded as calm at all locations in the area, as described above. On all these nights, we recorded differences in track directions between lowlands and mountain sites which were not due to differences in wind velocity.

Synoptic code 3 resulted in widely scattered tracks at all sites (Fig. 4). In many cases, often on the same night, birds appeared to move in almost opposite directions at neighboring sites. Movements above lowlands were primarily northeast and southwest parallel to the mountain range. In the pass and above ridges, movements often did not follow contour lines and it was difficult to discern any influence of local topography on direction of movement. Local winds for those observations were calm or $<8$ $\mathrm{m} \mathrm{s}^{-1}$ southerly.

Under synoptic codes 4 and 5, ridge sites were usually obscured by clouds, but on two of eight nights there were sufficient breaks in the clouds to use the ceilometers; a total of only three birds was seen on both nights indicating a paucity of migrants at those altitudes. In the pass, birds were moving northwest. Movements above lowlands were widely scattered. We conclude that those conditions, generally favorable for northward (spring) migration, were associated with north or northwest movements at low elevation and few birds flew at
$>1,000 \mathrm{~m}$ altitude. Winds were southerly at 5 to $8 \mathrm{~m} \mathrm{~s}^{-1}$. (No statistical test was done combining sites and weather codes because both summed sites for all weather codes and summed weather codes for all sites gave significant differences [see above] and we wished to avoid repeated tests.)

On a few occasions, we observed birds in process of encountering a change in wind conditions without appearing to change orientation. Within the pass itself, we repeatedly observed tracks of birds that moved south into the pass and then appeared to slowly retrace their path northward. These "retro" birds (Larkin and Thompson 1980) were seen on nights when strong south winds were recorded in the mountains, but not north of the Notch. We interpreted those tracks as birds encountering strong south winds and then being blown backwards without reorienting their flights. On 17 September 1992, we were able to directly observe the phenomenon with a ceilometer. A passerine entered the light beam at Cannon Mountain as it encountered the southerly wind above the summit. The bird maintained its southward heading, beating its wings steadily without making forward progress. It then began to move slowly backwards still heading south and beating its wings until it disappeared.

Comparison of diurnal and nocturnal observations.-Changes in diurnal census data were associated with specific patterns of nocturnal migratory behavior observed by radar and ceilometer. Density of bird tracks detected with radar, however, was not reduced on nights when the census data indicated stable numbers of migrants in the area. Major changes in number of migrants on the ground, as indicated by the migration index for diurnal census data, were associated with southwest and southward movements the previous night as shown in Figure 5. Average track-density index was $123.4 \pm 57.4$ on these nights. Minor changes in diurnal migration index were associated with nocturnal southwest or southward movements at all sites and an average density index of $107.5 \pm 68.5$ tracks. At the lower elevation sites, there were also significant numbers of tracks moving north (Fig. 5). When the diurnal migration index indicated stable numbers of migrants, nocturnal movements were generally scattered (Fig. 5.) with an average density index of $\mathbf{1 4 1 . 2}$ \pm 59.3 . Analysis of variance showed no signif- 
Major changes

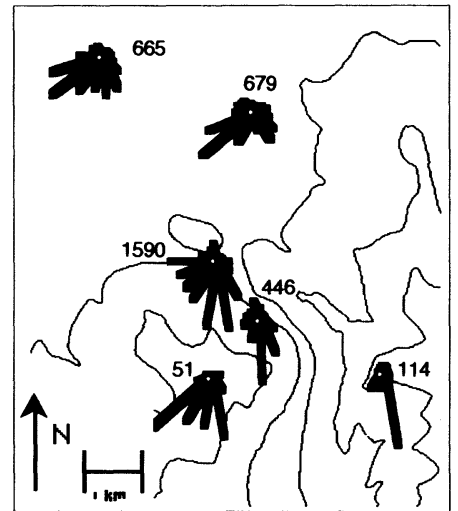

Minor changes

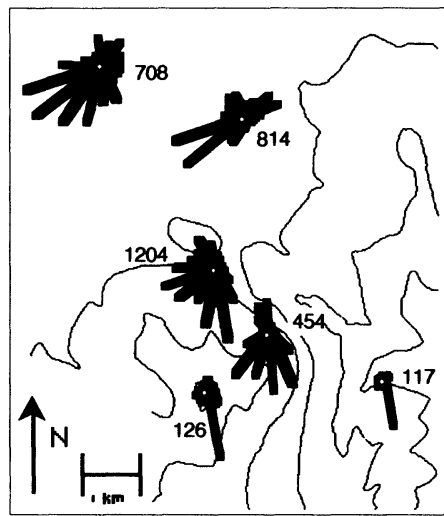

No change

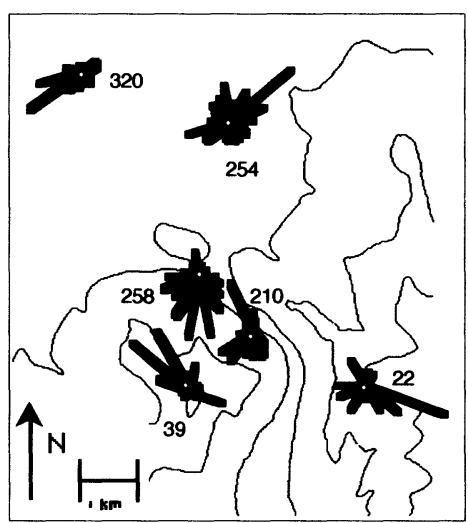

FIG. 5. Distribution of tracks of nocturnal migrants in Franconia Notch, New Hampshire, for three levels of migratory index derived from census counts the next morning: major changes in relative numbers of migrants from previous day (16 nights), minor changes (15 nights), and no discernible change (7 nights). Circular histograms as in Figure 4.

icant difference between the density of tracks under the three migratory index conditions $(F$ $=0.661, P=0.523)$. The Batschelet $\chi^{2}$ test showed a significant association between those migration-index categories and direction of migrants recorded at all nocturnal observation sites $\left(\chi^{2}=277, \mathrm{df}=34, P<0.0001\right)$. Nights with modal track patterns of south, southwest, or north were associated with large or moderate changes in diurnal census, whereas nights with modal track patterns east-west were associated with minor changes or stable numbers of migrants $\left(\chi^{2}=9.2, \mathrm{df}=2, P=0.01\right)$.

Comparison of census results and nocturnal observations did not indicate an association of orientation behavior with either specific species or species groups. Daily census of birds indicated three migratory periods during our observations (Fig. 2): early migrants (largely Neotropical warblers), mid-season (primarily
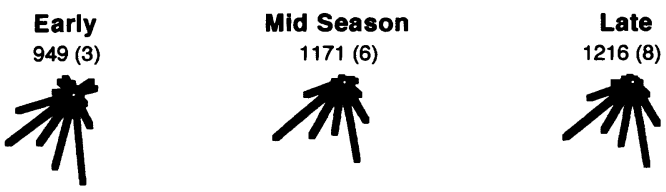

FIG. 6. Track distributions on nights with weather code 1 or 2 . Total of all radar and ceilometer sites for early, mid-season and late migratory periods as defined by daily census data. Circular histograms as in Figure 3.
Yellow-rumped Warblers), and late (mostly robins and juncos, Fig. 2). There were significant differences between the density of migrants recorded by radar during the three periods. The early period was relatively light with an average track-density index of $86.9 \pm 63.2$. In midseason, radar recorded a higher density, average $154.0 \pm 42$; late season decreased to an average of $82.3 \pm 60.4$ (ANOVA: $F=8.05, P=$ $0.0013)$. Those periods did not correspond to marked differences in distribution of nocturnal migrant track directions as seen on radar and ceilometer. We selected nights with synoptic code 1 or 2 to obtain greatest probability of detecting southbound migrant birds rather than birds moving locally. All three migratory periods showed patterns of tracks at each site similar to those shown for codes 1 and 2 (Fig. 4), and therefore we summed all sites for analysis (Fig. 6). All three seasonal categories showed the same southwest and south-southeast modal track directions. The Batschelet $\chi^{2}$ test showed a significant association between the distribution of track direction and migratory period $\left(\chi^{2}=157, \mathrm{df}=30, P<0.0001\right)$, but those differences were due to relatively minor differences in numbers of tracks in each of the south and southwest direction bins rather than a pronounced shift in any major directional tendency. Analysis of nightly patterns of migration supported this conclusion. There was no sig- 
nificant association between nights with modal directions to the south versus soutwest and season, or with any group of species in diurnal census counts.

\section{DISCUSSION}

The combination of high-resolution radar, ceilometers, and daily ground counts at multiple sites provided a view of autumnal migration through complex topography at a resolution not previously attained in North America. The lowest $300 \mathrm{~m}$ of bird migration (which we observed) probably represent the most dense stratum of nocturnal migrants (Eastwood 1967, Able 1970, Bruderer and Jenni 1988). Direction of movements we observed at low altitude agree well with those observed at greater altitudes by Drury and Keith (1962) and Williams et al. (1977) using surveillance and weather radars on Cape Cod. Primary directions of movement in both those studies were to the southwest and south-southeast. Drury and Keith (1962) interpreted those as movements along the New England coastline (southwest) and away from the coast, over the Atlantic Ocean. We found those same primary directions of movement $120 \mathrm{~km}$ inland. As in previous radar studies in North America, we found synoptic weather to be the most important factor in stimulating and maintaining autumnal migration. Southward migration is heaviest west of a cold front and east of a high-pressure center. Southward movements are less dense west of high pressure and after passage of a warm front (Drury and Keith 1962, Lowery and Newman 1966, Richardson 1972, 1978b; Williams et al. 1977, Able 1980). Our results differ from those studies primarily in the high density movements we recorded at low altitudes during periods of unfavorable weather, such as weather code 3 (compare Richardson 1978b). That difference is not entirely due to low altitude of migrants we observed. Able (1973) also observed low-altitude migrants in the southeastern United States, but did not record dense movements under unfavorable conditions. Our observations were made within breeding areas of most species we used for analysis. We also ended the study before killing frosts removed most insects from the area. Our diurnal observations suggested movement to abundant food sources and avoidance of hazardous local weather conditions, as well as southward migration, as a reason for movement. Richardson (1982) reviews other possible interpretations of reverse migration and Williams and Webb (1996) have shown the importance of search behavior in evolution of bird migration in North America. Our observations suggest that such movements are performed at night perhaps to avoid predation or to maximize feeding opportunities during the day. Alerstam (1978), Lindström and Alerstam (1986), and Lindström (1990) reached similar conclusions for migrants in northern Europe.

The principal difference between our results and those of previous studies in North America is departure from broadfront migration. We found clear differences in distribution of track directions above lowlands northwest of the mountains and within the mountains. It is our interpretation that those differences in direction of migration may be due to both topography and altitude, but not to local winds. Differences between orientation in lowlands and within Franconia Notch are probably due at least in part to topography. Sites are too close in altitude for differences to be due to elevation alone. Birds appear to move southwest along the face of the Franconia Range and deviate southward as they move through the pass. That is especially evident at site 3 where birds outside the entrance moved southwest and birds within the pass moved primarily southsoutheast. Altitude may play a more important role in simultaneous southwest movement of birds above lowlands and southward movements over the mountain ridges often observed during synoptic weather codes 1 and 2 . We interpret those data as two strata of migrating birds often separated by a thermal inversion. The lower layer in lowlands and valleys moves primarily southwest and the upper layer moves south or southeast. Depending upon altitude of the inversion, the upper layer may move up and over the mountain ridges in broadfront $\mathrm{mi}$ gration or may flow along the contours of the pass. Persistence of those patterns under calm wind conditions argues against downwind orientation to local wind conditions as the source of differences.

Our results are similar to extensive radar, infrared, and moon-watching studies within the area of the Alps in western Switzerland. Bruderer and Jenni (1990) found that although au- 
tumnal migration is broadfront in the sense that birds are moving over the entire area in the same general direction, land forms have a significant guiding effect. Birds within mountain valleys flying at 30 to $1,000 \mathrm{~m}$ AGL were more influenced by topography and showed more variability in direction over the study area than were those above 1,000 $\mathrm{m}$ AGL. When approaching the Alps, birds flying at $<1,000 \mathrm{~m}$ tend to deviate to fly parallel to mountain ridges unless those ridges are more or less perpendicular to their flight. Birds moving above $1,500 \mathrm{~m}$ and those meeting ridges perpendicular to their flight direction tend to fly over ridges in broadfront migration (Bruderer 1978, 1996; Bruderer and Jenni 1990). Southward migrating birds encountering the Alps deviate their flight southwest and move parallel to the face of the mountain range with smaller numbers penetrating through passes in the mountains (Liechti et al. 1996, Bruderer and Liechti 1999). Other similarities between our work and Bruderer's include an increased effect of topographical cues in unfavorable winds, dense movements in seasonally inappropriate directions, and retro flights of birds encountering strong winds as they crest a ridgeline (Bruderer 1999). Liechti and Bruderer (1995) also found birds responding to topography over highlands of southern Israel although the effect was not as pronounced as in the Alps. McKernan and his coworkers used ceilometers in mountain passes of southern California and found that ". . topographic relief (mountain passes) have greater magnitude [of migration] than other sites without relief (e.g. Mojave and Colorado Deserts). Mean angles for those nocturnal migrants within the topographic relief were aligned with the orientation of the relief." (R. McKernan pers. comm.).

Arrivals and departures of birds inferred from our diurnal visual census were clearly related to nocturnal flight behavior as observed with ceilometers and radar. Southward or northward nocturnal movements were more clearly associated with changes in ground counts than in previous studies (Nisbet and Drury 1967, Williams et al. 1981). That was probably due to our summing data from several sites for nocturnal observations and several widely separated, ecologically diverse areas for diurnal census counts.
Our observations suggest a range of orientation techniques for nocturnal migrants depending upon weather conditions. Broadfront migration and observations of retro birds under synoptic codes 1 and 2 suggest fixed-heading orientation. Local flights and altitudinal movements under weather codes 3,4 , and 5, and reaction to topography of the Franconia Range and the mountain pass under all weather conditions suggest importance of land forms in other phases of orientation. Able (1982) also found differences in orientation depending on weather conditions, but he found birds exhibiting downwind orientation under conditions of overcast. A definitive test of importance of local wind direction was not possible for our data because wind direction and speed often differed greatly over the range of a single radar site or within the altitude range of the radar or ceilometer. However, synoptic weather codes predicted patterns of migration even in calm winds and we often observed a multimodal distribution of simultaneous tracks at a single site, presumably under similar wind conditions. Birds migrating through the turbulent and unpredictable wind conditions in mountains might find it dangerous to rely on downwind flight for orientation. Although local winds are relatively constant over flat terrain, birds migrating through the Franconia Range might benefit from using a more reliable feature such as synoptic weather or topography.

We were not able to relate nocturnal migratory behavior to specific species or groups of species with similar migratory goals, such as Neotropical warblers. Ground counts revealed that was probably because both Neotropical and North American migrants responded similarly to synoptic weather stimuli for migration. Both early and midseason migrations contained birds heading for both the Neotropics (southsoutheast) and southern North America (southwest), for example movements in late September contained not only Yellow-rumped Warblers and Northern Flickers, but also Blackpoll Warblers and Bicknell's Thrushes. Alerstam (1996) presents evidence for a range of orientation techniques across a much broader taxonomic spectrum than our birds, which were primarily passerines.

Our observations and those of Bruderer and his coworkers indicate that broadfront migration should not be assumed for the passage of 
avian migrants over mountainous areas (Bruderer 1996, Liechte et al. 1999). That is important for evaluation of structures such as wind-powered electrical generators or communication towers on ridge lines. Although our studies were not designed to observe concentration of migrants at topographical features, reaction of migrants to topography that we did observe suggested such concentrations during both favorable and unfavorable conditions. Concentrations could result either as birds moved along a corridor, such as a pass or ridge line, or they could result from birds moving up and over a ridge meeting migrants already at that altitude and thus producing large numbers of birds a few tens of meters above the ridge summit. Our ceilometer observations of large numbers of birds near crests of ridges are particularly relevant in that regard.

\section{ACKNOWLEDGMENTS}

We thank Eric Lane, Lisa Mosca, Hope Sieck, R. Douglas Sloane, and Rosanna Webb for their invaluable assistance in collection and analysis of data, Robert O. Williams, for help with equipment; Gudmund Iverson, Anne W. Lane, and Elizabeth Mallory for statistical advice; and Eric Lane, Ronald Larkin, W. John Richardson, and Rosanna Webb for comments on the manuscript. We are indebted to the Appalachian Mountain Club, the U.S. Forest Service, Franconia Notch State Park, and Cannon Mountain Ski Area for permission to use facilities and areas under their jurisdiction and for their cooperation in all phases of the project. The Appalachian Mountain Club provided communications equipment, and food and lodging at the Greenleaf Hut. The Cannon Mountain Ski Area provided transportation and lodging for operations at the summit station of Cannon Mountain. This project was supported by the Explorers Club Youth Activities Fund and by Swarthmore College through the Meinkoth and Enders Funds, the Lande Fund, the Natural Sciences Research Fund, the Faculty Research Fund, the Department of Biology, and the Faculty Leave Program.

\section{LITERATURE Cited}

ABLE, K. P. 1970. A radar study of the altitude of nocturnal passerine migration. Journal of Field Ornithology 41:282-290.

ABLE, K. P. 1972. Fall migration in coastal Louisiana and the evolution of migration patterns in the Gulf region. Wilson Bulletin 84:231-242.

ABLE, K. P. 1973. The role of weather variables and flight direction in determining the magnitude of nocturnal bird migration. Ecology 54:1031-1041.
Able, K. P. 1980. Mechanisms of orientation, navigation, and homing. Pages 283-373 in Animal Migration, Orientation, and Navigation (S. A. Gauthreaux, Jr., Ed.). Academic Press, New York.

ABLE, K. P. 1982. Field studies of avian nocturnal migratory orientation I. Interaction of sun, wind, stars as directional cues. Animal Behaviour 30: 761-767.

Able, K. P., and S. A. Gauthreaux, JR. 1975. Quantification of nocturnal passerine migration with a portable ceilometer. Condor 77:92-96.

AlERSTAM, T. 1978. Reoriented bird migration in coastal areas: dispersal to suitable resting grounds? Oikos 30:405-408.

AlerstAM, T. 1996. The geographical scale factor in orientation of migrating birds. Journal of Experimental Biology 199:9-19.

Batschelet, E. 1981. Circular Statistics in Biology. Academic Press, New York.

BERTHOLD, P. 1990. Genetics of migration. Pages 269283 in Bird Migration: Physiology and Ecophysiology (E. Gwinner, Ed.). Springer Verlag, Berlin.

Bingman, V. P., K. P. Able, AND P. Kerlinger. 1982. Wind drift, compensation, and the use of landmarks by nocturnal bird migrants. Animal Behaviour 30:49-53.

BLOCH, R., AND B. BRUDERER. 1982. The air speed of migrating birds and its relationship to the wind. Behavioral Ecology and Sociobiology 11:19-24.

BRUDERER, B. 1978. Effects of alpine topography and winds on migrating birds. Pages 252-265 in Animal Migration, Navigation, and Homing (K. Schmidt-Koenig and W. Keeton, Eds.). SpringerVerlag, Berlin.

BRUDERER, B. 1996. Vogelzugforschung im Bereich der Alpen 1980-1995. Der Ornitologische Beobachter 93:119-130.

BRUDERER, B. 1999. Three decades of tracking radar studies on bird migration in Europe and the Middle East. Pages 107-141 in Proceedings International Seminar on Birds and Flight Safety in the Middle East (Y. Leshem, Y. Mandelik, and J. Shamoun-Baranes, Eds.). Tel-Aviv, Israel.

BRUDERER, B., AND L. JENNI. 1988. Strategies of bird migration in the area of the Alps. Pages 21502161 in Acta XIX Congressus Internationalis Ornitologici (H. Ouellet, Ed.). National Museum of Natural Science, Ottawa, Ontario.

BRUderer, B., AND L. JeNNI. 1990. Migration across the Alps. Pages 61-77 in Bird Migration: Physiology and Ecophysiology (E. Gwinner, Ed.). Springer Verlag, Berlin.

BRUDERER, B., AND F. LIECHTI. 1999. Bird migration across the Mediterranean. Pages 1983-1999 in Proceedings XXII International Ornithology 
Congress (N. J. Adams and R. H. Slotow, Eds.). University of Natal, Durban, South Africa.

CoHen, B., AND T. C. Williams. 1980. Short-range corrections for migrant bird tracks on search radars. Journal of Field Ornithology 51:248-251.

DruRY, W. H., AND J. A. KEITH. 1962. Radar studies of songbird migration in coastal New England. Ibis 104:449-489.

EASTWOOD, E. 1967. Radar Ornithology. Methuen, London.

Gauthreaux, S. A., JR. 1969. A portable ceilometer technique for studying low level nocturnal migration. Journal of Field Ornithology 40:309319.

GaUthreaux, S. A., JR. 1980. Direct visual and radar methods for the detection, quantification, and prediction of bird migration. Special Publication no. 2, Department of Zoology, Clemson University, Clemson, South Carolina.

JELLMANN, J. 1988. Leitlinienwirkung auf den nächtlichen Vogelzug im Bereich der Mündungen von Elbe und Weser nach Radarbeobachtungen. Die Vogelwarte 34:208-215.

LARKIN, R. P. 1991. Flight speeds observed with radar, a correction: Slow "birds" are insects. Behavioral Ecology and Sociobiology 29:221-224.

LARKIN, R. P., AND D. THOMPSON. 1980. Flight speeds of birds observed with radar: Evidence for two phases of flight. Behavioral Ecology and Sociobiology 7:301-317.

LIECHTI, F., AND B. BRUDERER. 1995. Direction, speed, and composition of nocturnal bird migration in the south of Israel. Israel Journal of Zoology 41: 501-515.

Liechti, F., D. Peter, R. LARDELli, AND B. BRuderer. 1996. Herbstlicher Vogelzug im Alpenraum nach Mondbeobactungen-Topographie und Wind beeinflussen den Zugverlauf. Der Ornithologische Beobachter 93:131-152.

LINDSTRÖM, Å. 1990. The role of predation in habitat selection in migrating Bramblings Fringilla montifringilla. Behavioral Ecology 1:102-106.

LINDSTRÖM, Å., AND T. AlerstAM. 1986. Adaptive significance of reoriented migration of Chaffinches Fringilla coelebs and Bramblings F. montifringilla during autumn in southern Sweden. Behavioral Ecology and Sociobiology 19:417424.

LOWERY, G. H., JR., AND R. J. NeWMAN. 1966. A continent wide view of bird migration on four nights in October. Auk 83:547-586.
MCCrary, M. D., R. L. MCKernan, W. D. WAgner, R. E. LANDRY, AND R. W. SCHREIBER. 1983. Nocturnal avian migration assessment of the San Gorgonia wind resource study area, spring 1982. Report 83-RD-108 for Southern California Edison Co., Research and Development Division Los Angeles, California.

NISBET, I. C. T., AND W. H. DRURY. 1967. Orientation of spring migrants studied by radar. Bird-Banding 38:173-186.

RAYNOR, J. 1985. Flight, speeds of. Pages 224-226 in A Dictionary of Birds (B. Campbell and E. Lack, Eds.). Poyser, Staffordshire, United Kingdom.

RICHARDSON, W. J. 1972. Autumn migration and weather in eastern Canada: A radar study. American Birds 26:10-17.

RICHARDSON, W. J. 1978a. Reorientation of nocturnal landbird migrants over the Atlantic Ocean near Nova Scotia in autumn. Auk 95:717-732.

RICHARDSON, W. J. 1978b. Timing and amount of bird migration in relation to weather: A review. Oikos 30:224-272.

RICHARDSON, W. J. 1982. Northeastward reverse migration of birds over Nova Scotia, Canada, in autumn. Behavioral Biology and Sociobiology 10: 193-206.

Seilman, M. S., L. A. Sheriff, AND T. C. Williams. 1981. Nocturnal migration at Hawk Mountain, Pennsylvania. American Birds 35:906-909.

Williams, T. C. 1991. Constant compass orientation for North American autumnal migrants. Journal of Field Ornithology 62:218-225.

Williams, T. C., J. E. MARsDEN, T. L. Lloyd-Evans, V. Krauthamer, and H. Krauthamer. 1981. Spring migration studied by mist-netting, ceilometer, and radar. Journal of Field Ornithology 52:177-190.

WILliams, T. C., AND T. WEBB III. 1996. Neotropical bird migration during the ice ages: Orientation and ecology. Auk 113:105-118.

Williams, T. C., AND J. M. Williams. 1980. A Peterson's Guide to radar ornithology? American Birds 34:738-741.

Williams, T. C., J. M. Williams, L. C. IREland, AND J. M. TEAL. 1977. Autumnal bird migration over the western North Atlantic Ocean. American Birds 31:251-267.

WiltschKo, W., AND R. WILTSChKO. 1978. A theoretical model for migratory orientation and homing in birds. Oikos 30:177-187.

Associate Editor: F. Moore 
APPENDIX. Bird species with five or more birds observed in one day during 1992 and 1993 census. Status, and average and maximum numbers of birds per day at alpine and valley sites. Status codes: e $=e a r l y, 1$ $=$ late, $\mathrm{m}=$ midseason, $\mathrm{n}=$ nonmigrant during study period, $\mathrm{a}=$ altitudinal migrant.

\begin{tabular}{|c|c|c|c|c|c|c|}
\hline \multirow[b]{2}{*}{ Common name } & \multirow[b]{2}{*}{ Scientific name } & \multirow[b]{2}{*}{ Status } & \multicolumn{2}{|c|}{ Alpine } & \multicolumn{2}{|c|}{ Valley } \\
\hline & & & $\mathrm{Av}$ & Max & Av & Max \\
\hline Yellow-bellied Sapsucker & Sphyrapicus varius & $\mathrm{n}$ & 0 & 0 & 0.26 & 6 \\
\hline Northern Flicker & Colaptes auratus & $\mathrm{m}$ & 0.04 & 2 & 0.96 & 49 \\
\hline Blue-headed Vireo & Vireo solitarius & $\mathrm{n}$ & 0 & 0 & 0.53 & 7 \\
\hline Red-eyed Vireo & Vireo olivaceus & $\mathrm{e}$ & 0 & 0 & 0.29 & 7 \\
\hline Blue Jay & Cyanocitta cristata & $\mathrm{n}$ & 3.93 & 13 & 10.69 & 33 \\
\hline American Crow & Corvus brachyrhynchos & $\mathrm{n}$ & 0 & 0 & 2.98 & 13 \\
\hline Common Raven & Corvus corax & $\mathrm{n}$ & 1.32 & 11 & 1.20 & 6 \\
\hline Black-capped Chickadee & Poecile atricapillus & $\mathrm{n}$ & 2.65 & 17 & 10.09 & 38 \\
\hline Boreal Chickadee & Poecile hudsonicus & $\mathrm{n}$ & 13.8 & 26 & 0 & 0 \\
\hline Red-breasted Nuthatch & Sitta canadensis & $\mathrm{n}$ & 1.69 & 5 & 2.09 & 10 \\
\hline White-breasted Nuthatch & Sitta carolinensis & $\mathrm{n}$ & 0 & 0 & 1.09 & 5 \\
\hline Golden-crowned Kinglet & Regulus satrapa & a & 7.07 & 27 & 0.62 & 11 \\
\hline Ruby-crowned Kinglet & Regulus calendula & $\mathrm{a}$ & 3.13 & 22 & 0.60 & 8 \\
\hline Bicknell's Thrush & Catharus bicknelli & $\mathrm{e}$ & 0.84 & 11 & 0 & 0 \\
\hline Hermit Thrush & Catharus guttatus & $\mathrm{n}$ & 0.02 & 1 & 0.62 & 5 \\
\hline American Robin & Turdus migratorius & 1 & 0.27 & 2 & 4.07 & 28 \\
\hline Cedar Waxwing & Bombycilla cedrorum & e & 0 & 0 & 0.57 & 11 \\
\hline Neotropical warbler group & see below & & 3.27 & 18 & 3.44 & 33 \\
\hline Yellow-rumped Warbler & Dendroica coronata & $\mathrm{m}$ & 21.6 & 68 & 2.50 & 30 \\
\hline Common Yellowthroat & Geothlypis trichas & e & 0 & 0 & 1.60 & 13 \\
\hline Chipping Sparrow & Spizella passerina & $\mathrm{e}$ & 0.16 & 3 & 2.36 & 18 \\
\hline Song Sparrow & Melospiza melodia & $\mathrm{n}$ & 0 & 0 & 7.38 & 27 \\
\hline White-throated Sparrow & Zonotrichia albicollis & $\mathbf{a}$ & 6.98 & 21 & 4.04 & 34 \\
\hline White-crowned Sparrow & Zonotrichia leucophrys & 1 & 0.16 & 2 & 0.029 & 5 \\
\hline Dark-eyed Junco & Junco hyemalis & 1 & 16.80 & 60 & 2.42 & 50 \\
\hline Purple Finch & Carpodacus purpureus & $\mathrm{n}$ & 0 & 0 & 0.50 & 8 \\
\hline American Goldfinch & Carduelis tristis & $\mathrm{n}$ & 0.13 & 3 & 0.093 & 8 \\
\hline Evening Grosbeak & Coccothraustes vespertinus & $\mathrm{n}$ & 0 & 0 & 3.16 & 30 \\
\hline \multicolumn{7}{|c|}{ The following Neotropical warblers were treated as a single group. } \\
\hline Tennessee Warbler & Vermivora peregrina & $\mathrm{e}$ & 0.09 & 2 & 0.52 & 2 \\
\hline Nashville Warbler & Vermivora ruficapilla & $\mathrm{e}$ & 0 & $\overline{0}$ & 0.20 & 3 \\
\hline Yellow Warbler & Dendroica petechia & e & 0.09 & 2 & 0 & 0 \\
\hline Chestnut-sided Warbler & Dendroica pensylvanica & $\mathrm{e}$ & 0 & 0 & 0.13 & 6 \\
\hline Magnolia Warbler & Dendroica magnolia & $\mathrm{e}$ & 0.60 & 9 & 0.38 & 5 \\
\hline Black-throated Blue Warbler & Dendroica caerulescens & $\mathrm{e}$ & 0.12 & 2 & 0.38 & 5 \\
\hline Black-throated Green Warbler & Dendroica virens & e & 0.09 & 2 & 0.84 & 9 \\
\hline Blackburnian Warbler & Dendroica fusca & e & 0.13 & 2 & 0.22 & 4 \\
\hline Bay-breasted Warbler & Dendroica castanea & e & 0 & 0 & 0.02 & 1 \\
\hline Blackpoll Warbler & Dendroica striata & $\mathrm{m}$ & 1.27 & 10 & 0.22 & 5 \\
\hline Black-and-white Warbler & Mniotilta varia & $\mathrm{e}$ & 0.04 & 1 & 0.11 & 4 \\
\hline American Redstart & Setophaga ruticilla & $\mathrm{e}$ & 0 & 0 & 0.27 & 4 \\
\hline Ovenbird & Seiurus aurocapillus & e & 0.02 & 1 & 0.09 & 2 \\
\hline Wilson's Warbler & Wilsonia pusilla & e & 0.04 & 2 & 0.04 & 1 \\
\hline Canada Warbler & Wilsonia canadensis & e & 0 & $\overline{0}$ & 0.23 & 3 \\
\hline
\end{tabular}

